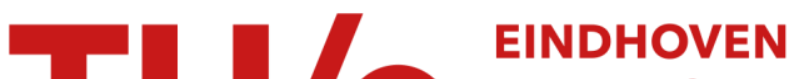 \\ UNIVERSITY OF \\ TECHNOLOGY
}

\section{Ventilation of operating theatres requires a performance}

\section{Citation for published version (APA):}

Loomans, M. G. L. C., Houdt, van, W., Lemaire, A. D., \& Hensen, J. L. M. (2006). Ventilation of operating theatres requires a performance. Journal of Hospital Infection, 64(Suppl. 1), S80-S80.

https://doi.org/10.1016/S0195-6701(06)60267-3

DOI:

10.1016/S0195-6701(06)60267-3

Document status and date:

Published: 01/01/2006

\section{Document Version:}

Accepted manuscript including changes made at the peer-review stage

\section{Please check the document version of this publication:}

- A submitted manuscript is the version of the article upon submission and before peer-review. There can be important differences between the submitted version and the official published version of record. People interested in the research are advised to contact the author for the final version of the publication, or visit the $\mathrm{DOI}$ to the publisher's website.

- The final author version and the galley proof are versions of the publication after peer review.

- The final published version features the final layout of the paper including the volume, issue and page numbers.

Link to publication

\section{General rights}

Copyright and moral rights for the publications made accessible in the public portal are retained by the authors and/or other copyright owners and it is a condition of accessing publications that users recognise and abide by the legal requirements associated with these rights.

- Users may download and print one copy of any publication from the public portal for the purpose of private study or research.

- You may not further distribute the material or use it for any profit-making activity or commercial gain

- You may freely distribute the URL identifying the publication in the public portal.

If the publication is distributed under the terms of Article 25fa of the Dutch Copyright Act, indicated by the "Taverne" license above, please follow below link for the End User Agreement:

www.tue.nl/taverne

Take down policy

If you believe that this document breaches copyright please contact us at:

openaccess@tue.nl

providing details and we will investigate your claim. 


\title{
Ventilation of Operating Theatres Requires a Performance
}

\author{
M. Loomans ${ }^{1}$, W. van Houdt ${ }^{2}$, A. Lemaire ${ }^{3}$, J. Hensen ${ }^{1}$ \\ ${ }^{1}$ Eindhoven University of Technology, Netherlands, ${ }^{2}$ Hospital Gooi-Noord, Netherlands, ${ }^{3}$ TNO, \\ Netherlands
}

Background: Due to infection risk, high demands are set for the air quality in operating theatres. As humans form the most important contamination source, ventilation of operating theatres is required. This is normally realised using a downflow plenum.

Aim/Objective: In this study a Performance Based (PB) approach was developed to allow testing of innovative ventilation design solutions for operating theatres. The paper describes the application of the approach, as well in the design stage as insitu, for an innovative downflow plenum that applies different temperature levels at the supply.

Methods: In the design stage the Computational Fluid Dynamics (CFD) technique was applied to evaluate the ventilation design. Evaluation was based on a performance requirement for the air quality, i.e. the contamination level above the operating and instrument tables should be lower than $10 \mathrm{CFU} / \mathrm{m}^{3}$ (ultraclean).

Boundary conditions for the contamination sources have been proposed. In the use phase, the actually built ventilation system was evaluated in-situ, applying a similar procedure as for the design evaluation.

Results: Application of the procedure in the design stage showed that objective PB optimisation of a ventilation design for operating theatres is possible. Based on the results design changes were proposed and the improvement was verified.

Application of the procedure in-situ was also successful. The measurement results indicated the correct performance and the agreement with the design results.

Discussion: The developed PB approach showed to be useful and open for assessment of innovative solutions. However, the applied static reference situation may be less representative.

Also, the application of the CFD-technique brings in specific assumptions that may affect the result. Future work therefore will focus on the evaluation under more realistic conditions. Furthermore, the PB approach is extended to, e.g., thermal comfort aspects, costs. 